\title{
プレストレスを導入した合成床スラブのたわみ性状に関する研究 STUDIES ON BEHAVIOR OF THE DEFLECTION OF COMPOSITE SLABS WITH PRESTRESSED PRECAST PANELS
}

\author{
田中恭哉*, 小森清司**, 原田哲夫*** \\ Kyouya TANAKA, Kiyoshi KOMORI and Tetsuo HARADA
}

\begin{abstract}
It is known that the deflection of composite slabs with prestressed precast panels on long-time bendings is small. Although only a few tests have been carried out, there were no analytical research. The authors proposed the analytical method to be useful for design and compared with the test results. The following results were obtained.

(1) This analytical method was able to estimate the deflection of composite slabs on short-time and long-time bendings accurately.

(2) From trial calculations, it was confirmed that the ratios of the deflections on long-time bendings to elastic deflections were from 5 to 8 .
\end{abstract} Keywords : composite slab, deflection curve, long-time bending, precast member, prestressed
concrete

\section{1.はじめに}

プレストレス構造のプレキャスト板（以下；PC 板とい う。）と場所打ち鉄脇コンクリートを合成した床スラブが, 建筑現場で使い始められておおよそ10年になる。近年で は，施工の省力化，スパンの長大化などのニーズから， 施工量も伸びつつある。これは，プレストレスを導入し た合成床スラブが，施工面の優位性牥勿論であるが，構 造面でも長期たわみやひびわれが少ない点で特に優れた 性能を有しているためと考えられ，この事坆筆者 ${ }^{1)-4)}$ をはじめ松崎ら ${ }^{7)}$ 等の実験で確認されている。

しかしながら，床スラブにおける最大の関心事は長期 たわみ性状の把握であると考えられるが, 解析的には唯 一鈴木ら ${ }^{8)}$ の提案が見受けられるだけで，学会規準等 ${ }^{91,10)}$ でも具体的な記述はない。現時点で使用されている合成 床スラブの設計は，それぞれの実験結果をもとに独自の クライテリアを設定して行っているのが実情である。こ れらの背景としては，この種の合成床スラブの断面形状 はリブ付きのものやフラット型のものなど様々有り，さ らに, 設計方法が引張応力を許さないフルプレストレス
からひびわれを許容した而種プレストレスまで広範囲に わたっており，この事が瞬時（弾性）拉よび長期たわみ の算定をより複雑にしていると考えられる。

今後, 省力化, プレキャスト化の傾向はますます強ま り, 用途, 必要性能に応じた合成床スラブの研究・開発 が行われるものと推測される。長期たわみについて実験 的に検討する場合には，長期間の歳月を必要とするのは 言うまでもなく，たわみ算定法の確立はますます重要性 を增すものと思われる。そこで，より合理的な解析手法 の提案が望まれるが，筆者らとしては現況を勘案すると 煩雑な解析法より，むしろ設計を対象とした簡便で精度 のよい解析法の確立が必要と考えている。

これまでに, 鉄筋コンクリート床スラブのたわみ解析 方法については，長期たわみの主要因と考えられる端部 上ば筋の梁部からの拔出し（以下，鉄筋の抜出しという。） やその経日変化についての研究がなされ，すでにいくつ かの解析方法が提案たと交(111),12) されている。また合成床ス ラブの特性であるコンクリートのクリープ, 収縮差によ る挙動についても坂ら ${ }^{13)}$ の研究がある。そこで本論では,

\footnotetext{
本論文は, 文献 1)～6) で報告したものを加筆，補足してまとめたものである。

* 長崎大学大学院海洋生産科学研究科

** 長崎大学工学部構造工学科 教授. 工博

Graduate School of Marine Science and Engineering, Nagasaki Univ.

長崎大学工学部構造工学科 助教授・工博

Prof., Dept. of Structural Engineering, Faculty of Engineering, Nagasaki Univ., Dr. Eng.

Assoc. Prof., Dept. of Structural Engineering, Faculty of Engineering, Nagasaki Univ., Dr. Eng.
} 
これら既往の研究成果を活用した任意形状断面の解析に 適用できる簡便な一解析法の提案を行い，その計算結果 を筆者らが行った短期, 長期載荷実験結果と比較し妥当 性を検証した。また, 同解析法を用いて実設計を対象と した試算を行い，合成床スラブのたわみ性状について検 討を行った。

\section{2. 短期載荷によるたわみ性状}

\section{1 実験概要}

\section{1) 試験体}

試験体は，チャンネル型（C 型），逆 $\mathrm{T}$ 型（ $\mathrm{R}$ 型）断 面を有する PC 板と場所打ち鉄筋コンクリートからなる実 大の合成床スラブであり，断面詳細を図ー 1 に，使用材 料の性質等を表一 $1 ， 2 ， 3$ に示寸。試験体は断面形状 が 3 種類からなり，それぞれに両端の支持状態が単純支 持 $(\mathrm{S})$, 両端固定 $(\mathrm{F})$ の 2 種類を設定し, 計 6 体とし た。スパンはいずれも $5.60 \mathrm{~m}$ である。また， PC 板にはプ レテンション方式により表ー3に示す所定のプレストレ スが導入されており，場所打ち部との一体性を確保する ため PC 板上面にはひし形網目上の粗面仕上げ'19)を施し た。なお，R20S，R20F (それぞれ文献)における PRCS 2-(S)-1, PRCS2-1 試験体であるが，本稿では試験体記号 をR20S，R20F として表記する。）は断面内に中空部を有 する床スラブであるが, 両端から中央へ向かって $30 \mathrm{~cm} の$ 区間だけ中空部を場所打ちコンクリートで埋め殺してお り, 図一 1 に示す中空断面はスパン中間部の $5 \mathrm{~m}$ 区間だ けとなっている。また，R18S，R18F (それぞれ文献)に おける PRCS(S)-1， PRCS-1 試験体であるが，本稿では $\mathrm{R} 18 \mathrm{~S} ， \mathrm{R} 18 \mathrm{~F}$ として表記する。）はスラブ作成時にスパン 中央部の応力を軽減するため, 中間に支保工を設けて場 所打ちコンクリートを打設し場所打ち部の材令28日目で 支保工を撤去して作製した。他の試験体については，す ベて無支保工状態で場所打ちコンクリートを打設し, 作 製した。

\section{2) 実験方法}

載荷は, $30 \mathrm{tf}$ 油圧式門型試験機を用い, 図一 2 に示す よ5にスパン $5.60 \mathrm{~m}$ に対し， 3 等分点 2 点集中載荷とし た。加力サイクルは，(1)弹性範囲内（端部ひびわれ発生 荷重計算值の $60 \%$ ), (2)端部上面ひびわれ発生（両端固定
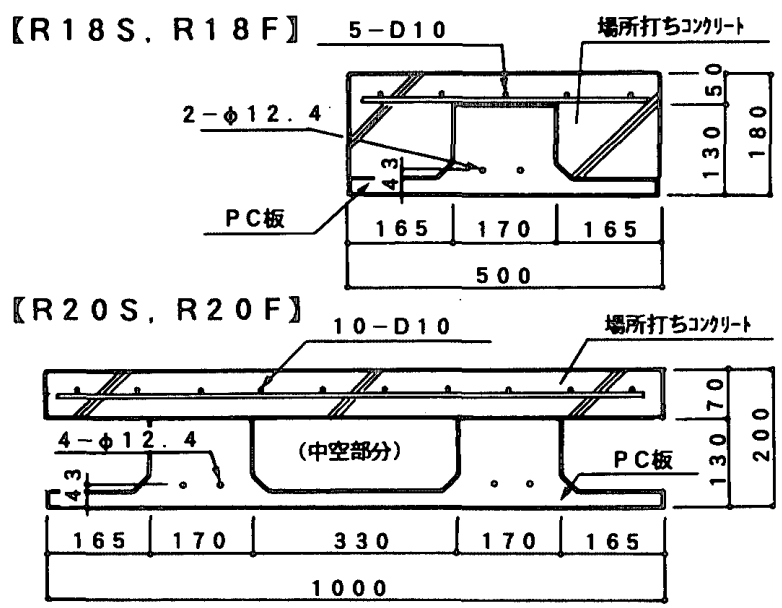

【C $25 \mathrm{~S}, \mathrm{C} 25 \mathrm{~F} \rrbracket 5-D 10$

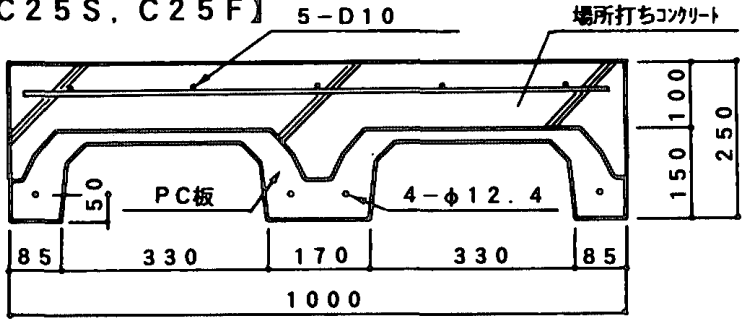

图一1 試験体断面詳細

表ー1 コンクリートの性質

\begin{tabular}{|c|c|c|c|c|}
\hline & \multicolumn{2}{|c|}{ P C 板 部 } & \multicolumn{2}{|c|}{ 埥 所 打 部 } \\
\hline & $\begin{array}{c}\text { 珐㴼 強度 } \\
\sigma_{\mathrm{B}}, \mathrm{pc} \\
\left(\mathrm{kgf} / \mathrm{cm}^{2}\right)\end{array}$ & $\begin{array}{c}\text { 弾姓 你数 } \\
E \text { pc } \\
\left(\mathrm{kg}^{\prime} / \mathrm{cm}^{2}\right)\end{array}$ & 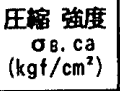 & $\begin{array}{c}\text { 弾性 的数 } \\
E \mathrm{ca} \\
\left(\mathrm{kg} / \mathrm{\textrm {cm } ^ { 2 }}\right)\end{array}$ \\
\hline$R 18 \mathrm{~S}$ & 580 & $3.3 \times 10^{5}$ & 290 & $2.9 \times 10^{5}$ \\
\hline R18F & 602 & $3.3 \times 10^{5}$ & 312 & $3.0 \times 10^{5}$ \\
\hline R20S & 588 & $2.9 \times 10^{5}$ & 260 & $2.4 \times 10^{5}$ \\
\hline $\mathrm{R} 20 \mathrm{~F}$ & 542 & $2.9 \times 10^{5}$ & 280 & $2.6 \times 10^{5}$ \\
\hline $\mathrm{C25S}$ & 588 & $2.9 \times 10^{5}$ & 260 & $2.4 \times 10^{5}$ \\
\hline $\mathrm{C} 25 \mathrm{~F}$ & 542 & $2.9 \times 10^{5}$ & 280 & $2.6 \times 10^{5}$ \\
\hline
\end{tabular}

表ー2 PC 鋼材抢よび鉄筋等の性質

\begin{tabular}{|c|c|c|c|c|c|c|}
\hline & 栖頪の記号 & $\begin{array}{r}\text { 酘面棈 } \\
\left(\mathrm{m}^{2}\right)\end{array}$ & 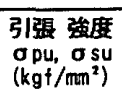 & 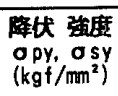 & 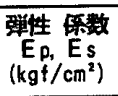 \\
\hline & R18 & & 92.90 & 1,9 & 174 & $1.9 \times 10^{\circ}$ \\
\hline 籍 & R20. C25 & & & & & $1.9 \times 10^{\circ}$ \\
\hline 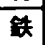 & 818 & & 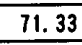 & & & $1.9 \times 10^{\circ}$ \\
\hline 策 & \begin{tabular}{|l} 
R20, C25 \\
\end{tabular} & & & & & $19 \times 10^{0}$ \\
\hline & & & & - & & $2.0 \times 10$ \\
\hline
\end{tabular}

表ー3 試験体のプレストレス

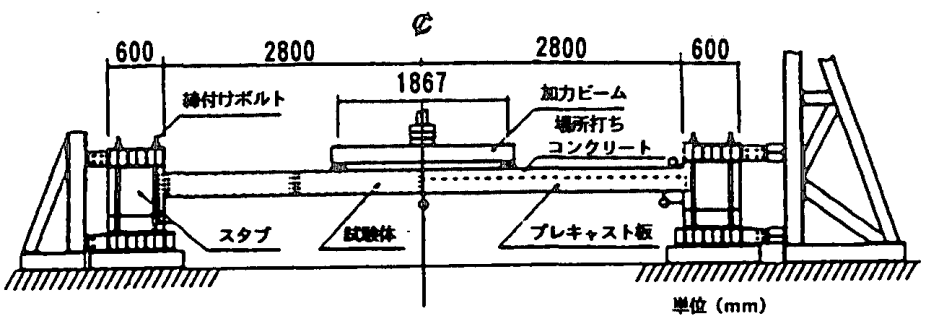

\begin{tabular}{|c|c|c|c|}
\hline & \multirow{2}{*}{ 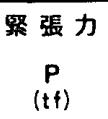 } & \multicolumn{2}{|c|}{ プレストレス } \\
\hline & & 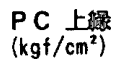 & 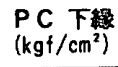 \\
\hline $\mathrm{R} 18$ 用PC板 & 18.64 & 38.8 & 73.8 \\
\hline $\mathrm{R} 20$ 用PC板 & 39.48 & 41.1 & 78.1 \\
\hline C 25用PC板 & 41.80 & 3.0 & 152.4 \\
\hline
\end{tabular}

图-2 載荷要領図（両端固定の場合） 
試験体のみ), (3) PC 板下面のひびわれ発生, (4)終局まで の3〜4サイクルとした。測定は, 荷重をロードセルで, スパン中央部および端部の変位を変位計で測定した。ま た, R20 および C25については, 試験体側面のスラブ上, 下縁より $1.5 \mathrm{~cm}$ 内側線上の伸縮を検長 $10 \mathrm{~cm}, 30 \mathrm{~cm}$ のパイ ゲージで測定した。

\section{2 短期たわみの算定法}

短期載荷時のたわみは，断面の釣合いよりモーメントー 曲率関係（以下， $\mathrm{M}-\phi$ 関係という。）を求め，モールの定 理により計算を行う。

解析上の仮定は，以下のとおりである。

\section{1) 材料の性質}

図ー3に各材料の応力度一ひずみの関係を示す。コン クリートの応力度一ひずみの関係は，PC 板部を二次関数 で，場所打ち部を $\mathrm{e}$ 関数で表示する。なお，引張に対し てはフックの法則に従い, 所定のひずみを越えた場合は 引張力を無視する。また，PC 鋼材の場合は, Tri-linear 型，鉄筋等の場合は Bi-linear 型とする。

2) M- $\phi$ 関倸

\section{a 、スパン中央部}

合成断面では, プレストレスが導入された PC 板と場所 打ちコンクリートとの合成部材となるため, 断面内のひ ずみ分布は不連続になる。ここで，PC 板断面および合成 断面においてそれぞれに作用する曲げ応力に対し平面保 持を仮定し，合成断面のひずみ分布はそれらが合成され たものとすると，図一 4 a に示すひずみ分布が得られる。 よって，同図より下式を得ることができる。

$$
\begin{aligned}
& { }_{c} \mathrm{C}=\mathrm{C}_{1}+\mathrm{C}_{2}+\mathrm{C}_{\mathrm{s}} \\
& { }_{\mathrm{c}} \mathrm{T}=\mathrm{T}_{1}+\mathrm{T}_{2}+\mathrm{T}_{\mathrm{s}}+\left(\mathrm{P}_{0}+\Delta \mathrm{P}\right)
\end{aligned}
$$

軸方向力の钓合より

$$
{ }_{c} \mathrm{C}={ }_{\mathrm{c}} \mathrm{T}
$$

曲げモーメントは,

$$
\begin{aligned}
& { }_{\mathrm{c}} \mathrm{M}={ }_{\mathrm{c}} \mathrm{C} \cdot{ }_{\mathrm{c}} \mathrm{j}={ }_{\mathrm{c}} \mathrm{T} \cdot \mathrm{c} \mathrm{j} \\
& { }_{\mathrm{c}} \mathrm{M}_{\mathrm{p}}={ }_{\mathrm{c}} \mathrm{M}-{ }_{\mathrm{c}} \mathrm{M}_{\mathrm{d}} \cdots
\end{aligned}
$$

よって, $\mathrm{cM}_{\mathrm{p}}$ による断面曲率は,

$$
{ }_{\mathrm{c}} \phi=\frac{\varepsilon_{\mathrm{ctu}}}{\mathrm{x}_{1}}
$$

$$
\text { ここに, }
$$

$$
\begin{aligned}
& \mathrm{C}_{1}=\int_{\mathrm{D}-\mathrm{x}_{1}}^{\mathrm{D}}\left\{\sigma_{\mathrm{p}}(\mathrm{x}) \cdot \mathrm{b}_{\mathrm{p}}(\mathrm{x})+\sigma_{\mathrm{c}}(\mathrm{x}) \cdot \mathrm{b}_{\mathrm{c}}(\mathrm{x})\right\} \mathrm{dx} \cdots(7) \\
& \mathrm{C}_{2}=\int_{\mathrm{n}-\mathrm{x}_{2}}^{\mathrm{n}}\left\{\sigma_{\mathrm{p}}(\mathrm{x}) \cdot \mathrm{b}_{\mathrm{p}}(\mathrm{x})+\sigma_{\mathrm{c}}(\mathrm{x}) \cdot \mathrm{b}_{\mathrm{c}}(\mathrm{x})\right\} \mathrm{dx} \quad \cdots(8) \\
& \mathrm{T}_{1}=\int_{\mathrm{h}}^{\mathrm{D}-\mathrm{x}_{1}}\left\{\sigma_{\mathrm{p}}(\mathrm{x}) \cdot \mathrm{b}_{\mathrm{p}}(\mathrm{x})+\sigma_{\mathrm{c}}(\mathrm{x}) \cdot \mathrm{b}_{\mathrm{c}}(\mathrm{x})\right\} \mathrm{dx} \cdots(9) \\
& \mathrm{T}_{2}=\int_{0}^{\mathrm{h}-\mathrm{x}_{2}}\left\{\sigma_{\mathrm{p}}(\mathrm{x}) \cdot \mathrm{b}_{\mathrm{p}}(\mathrm{x})+\sigma_{\mathrm{c}}(\mathrm{x}) \cdot \mathrm{b}_{\mathrm{c}}(\mathrm{x})\right\} \mathrm{dx} \quad \cdots(10) \\
& \mathrm{C}_{\mathrm{s}}=\varepsilon_{\mathrm{sc}} \cdot \mathrm{A}_{\mathrm{c}} \cdot \mathrm{E}_{\mathrm{s}} \\
& \mathrm{T}_{\mathrm{s}}=\varepsilon_{\mathrm{st}} \cdot \mathrm{A}_{\mathrm{s}} \cdot \mathrm{E}_{\mathrm{s}} \\
& \Delta \mathrm{P}=\Delta \varepsilon_{\mathrm{p}} \cdot \mathrm{A}_{\mathrm{p}} \cdot \mathrm{E}_{\mathrm{s}}
\end{aligned}
$$

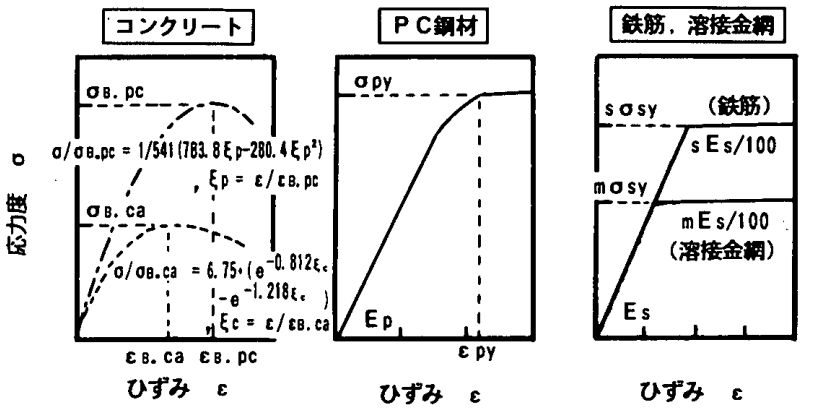

図ー3 材料の応カーひずみ関係
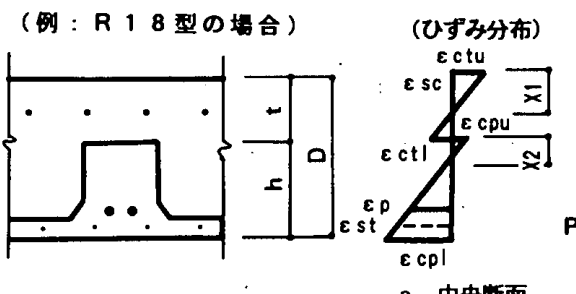

(力の䠼(1)
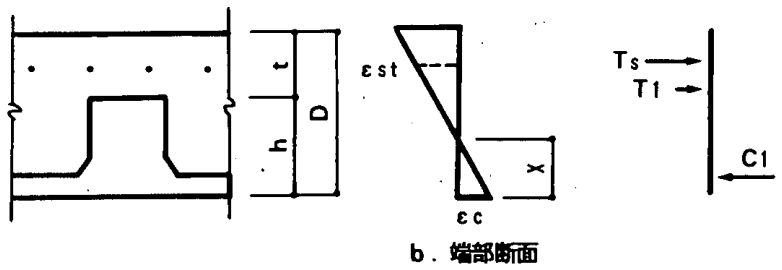

図ー4 ひずみ分布および力の釣合い

$$
\begin{array}{ll}
\text { ただし, } & \varepsilon<0 \text { の時 } \sigma_{\mathrm{p}}(\mathrm{x})=\varepsilon \cdot \mathrm{E}_{\mathrm{pc}} \\
& \varepsilon<0 \text { の時 } \sigma_{\mathrm{c}}(\mathrm{x})=\varepsilon \cdot \mathrm{E}_{\mathrm{ca}} \\
& \sigma_{\mathrm{p}}(\mathrm{x})<-0.07 \cdot \sigma_{\mathrm{B} . \mathrm{pc}} \text { の時 } \sigma_{\mathrm{p}}(\mathrm{x})=0 \\
& \sigma_{\mathrm{c}}(\mathrm{x})<-1.2 \sqrt{\sigma_{\mathrm{B} . \mathrm{ca}}} \text { の時 } \sigma_{\mathrm{c}}(\mathrm{x})=0
\end{array}
$$

ここに,

$$
\mathrm{P}_{\mathrm{o}}: \mathrm{PC} \text { 鋼材緊張力 }
$$

- $\triangle \mathrm{P}: \mathrm{PC}$ 鋼材の増加軸力

$\sigma_{\mathrm{p}}(\mathrm{x})$ ：PC 板部のコンクリート応力度

$\sigma_{\mathrm{c}}(\mathrm{x})$ : 場所打ち部のコンクリート応力度

$\mathrm{b}_{\mathrm{p}}(\mathrm{x}): \mathrm{PC}$ 板部の断面幅

$\mathrm{b}_{\mathrm{c}}(\mathrm{x})$ : 場所打ち部の断面幅

$\mathrm{A}_{\mathrm{c}}$ ：スパン中央部の圧縮鉄筋断面積

$\mathrm{A}_{\mathrm{s}}$ : スパン中央部の引張鉄筋断面積

$A_{p}: P C$ 鋼材断面積

$\mathrm{E}_{\mathrm{s}}$ : 鉄筋の弾性係数

$\mathrm{E}_{\mathrm{p}}: \mathrm{PC}$ 鋼材の弾性係数

$\mathrm{E}_{\mathrm{pc}}: \mathrm{PC}$ 板部コンクリートの弾性係数

$\mathrm{E}_{\mathrm{ca}}$ ：場所打ち部コンクリートの弾性係数

$\varepsilon:$ コンクリートのひずみ

${ }_{c} \mathrm{M}_{\mathrm{p}}$ ：載荷荷重による曲げモーメント

cM：断面に作用する全曲げモーメント

$\mathrm{cj}$ : 圧縮合力と引張合力の応力中心間距離 
cMd：荷重載荷前に作用した曲げモーメント

cф：載荷荷重による中央断面の曲率

$\mathrm{X}_{1}$ : 中立軸位置

次にたわみ算定上は，ひびわれのない区間を含む平均 的な曲率を用いる必要がある。ここでは，下式のように 猪股 ${ }^{14)}$ による平均曲率 $\mathrm{c} \phi_{\mathrm{av}}$ に修正して用いた。

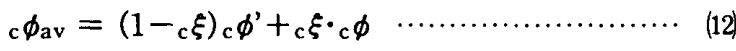

c $\xi=1-\left(\frac{{ }^{c} M_{c}-M_{0}}{c M-M_{0}}\right)^{2}$

ただし, ${ }_{\mathrm{c}} \mathrm{M}<{ }_{\mathrm{c}} \mathrm{M}_{\mathrm{c}}$ の時 $\mathrm{c} \xi=0$

ここに

cゆ'：ひびわれなしと仮定して求めた曲率

${ }_{\mathrm{c}} \mathbf{M}_{\mathbf{c}}$ : スパン中央部のひびわれ発生曲げモーメント

$\mathrm{M}_{0}$ : 引張縁応力度が 0 となる時の曲げモーメント

cM：スパン中央断面に作用する曲げモーメント

b. 端 部

端部断面においても同様に，図一 $4 \mathrm{~b}$ に示すひずみ分布 を想定すれば下式が得られる。なお，材端部のプレスト レスの分布は，文献）より図ー5に示すように仮定し考 慮した。

$$
\begin{aligned}
& { }_{\mathrm{e}} \mathrm{C}=\int_{0}^{\mathrm{x}}\left\{\sigma_{\mathrm{p}}(\mathrm{x}) \cdot \mathrm{b}_{\mathrm{p}}(\mathrm{x}) \sigma_{\mathrm{c}}(\mathrm{x}) \cdot \mathrm{b}_{\mathrm{c}}(\mathrm{x})\right\} \mathrm{dx} \quad \cdots \cdots \cdots
\end{aligned}
$$

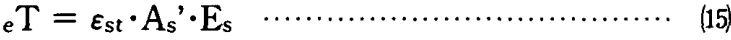

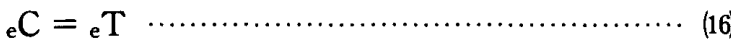

$$
\begin{aligned}
& { }_{e} \mathrm{M}={ }_{\mathrm{e}} \mathrm{C} \cdot \mathrm{ej}_{\mathrm{j}}={ }_{\mathrm{e}} \mathrm{T} \cdot \mathrm{ej}_{\mathrm{e}} \quad \ldots \ldots \ldots \ldots \ldots \ldots \ldots \ldots \ldots \ldots, \quad(17)
\end{aligned}
$$

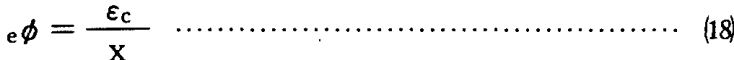

$$
\begin{aligned}
& { }_{\mathrm{e}} \phi_{\mathrm{av}}=\left(1-\mathrm{e}_{\mathrm{e}} \xi\right)_{\mathrm{e}} \phi^{\prime}+{ }_{\mathrm{e}} \xi \cdot{ }_{\mathrm{e}} \phi \ldots \ldots \ldots \ldots \ldots \ldots \ldots \ldots \ldots \ldots \ldots \ldots \ldots \ldots \ldots \\
& e \xi=1-\left(\frac{e M_{c}}{e}\right)^{2}
\end{aligned}
$$

ただし, $\mathrm{e}_{\mathrm{e}} \mathrm{M}<_{\mathrm{e}} \mathrm{M}_{\mathrm{c}}$ の時 $\mathrm{e} \xi=0$

ここに,

$\mathrm{A}_{\mathrm{s}}^{\prime}$ ：端部端面の上ば筋量

eф : ひびわれなしと仮定して求めた曲率

${ }_{\mathrm{e}} \mathrm{M}_{\mathrm{c}}$ : 端部のひびわれ発生曲げモーメント

eM：端部断面に作用する曲げモーメント

$\mathrm{ej}$ : 圧縮合力と引張合力の応力中心間距離

$\mathrm{e} \phi_{\mathrm{av}}$ : 端部断面に平均曲率

なお計算では，部材断面を $5 \mathrm{~mm}$ ピッチで高さ方向に細 分して行うこととし，そのフローを図ー6に示す。

3）曲げモーメントの分布

M- 関係を用いるにあたり，各断面位置に作用する曲 げモーメントを決定する必要がある。曲げモーメントの 分布は, 端部および中央部の剛性で変化するため, ここ では端部断面に作用するモーメントの値を完全固定とし た場合による值で除した分布係数 $\alpha$ を用いて表す。 $\alpha$ は， 端部降伏までとそれ以後で区別した。まず端部降伏ま で（ $\alpha_{1} ）$ は，スタブ固定部を等価な剛性，断面積を有す

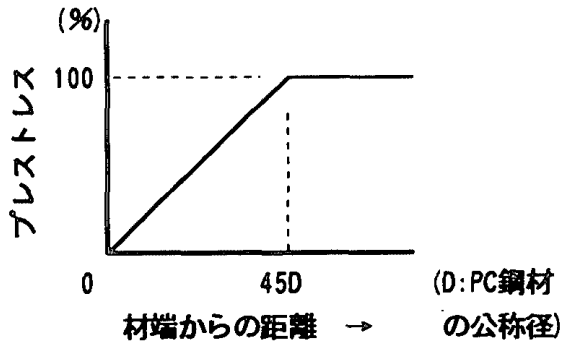

図ー5 材端部のプレストレスの分布

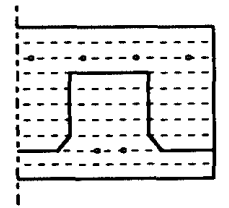

(餘面)

（ひずみ分布）

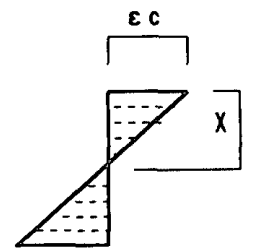

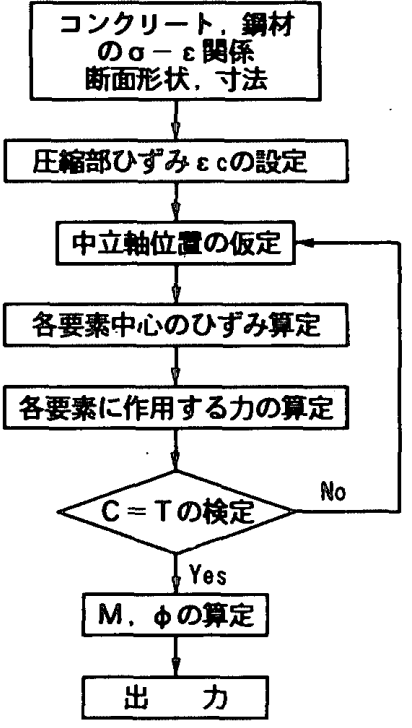

図-6 M- $\mathrm{M}$ 関係の計算フロー

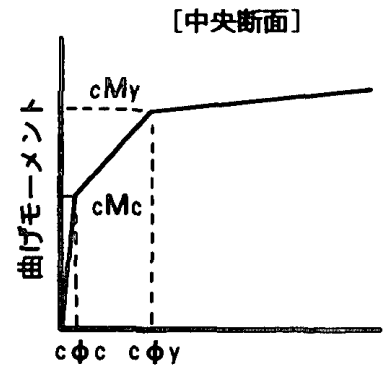

曲帮

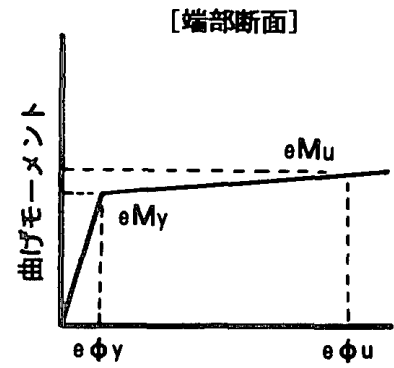

曲 紋
図-7 分布係数 $\alpha_{2}$ の算定方法

る骨組みに置き換え, 応力解析した結果で決定した。 次に終局まで $\left(\alpha_{2}\right)$ は，スパン内の曲率の釣合いと荷重 による仕事量の釣合いから下記の算定方法によった。(図一 7 参照)

$$
\Delta_{\mathrm{c}} \mathrm{M}=\frac{\Delta_{\mathrm{c}} \phi}{\beta_{\mathrm{c}}}, \quad \Delta_{\mathrm{e}} \mathrm{M}=\frac{\Delta_{\mathrm{e}} \phi}{\beta_{\mathrm{e}}}
$$

${ }_{\mathrm{c}} \mathrm{B} \cdot \Delta_{\mathrm{c}} \phi={ }_{\mathrm{e}} \mathrm{B} \cdot \Delta_{\mathrm{e}} \phi$ $(22)$

$\beta_{\mathrm{c}}=\frac{\left({ }_{\mathrm{c}} \phi_{\mathrm{y}}-{ }_{\mathrm{c}} \phi_{\mathrm{c}}\right)}{\left({ }_{\mathrm{c}} \mathrm{M}_{\mathrm{y}}-{ }_{\mathrm{c}} \mathrm{M}_{\mathrm{c}}\right)}, \quad \beta_{\mathrm{e}}=\frac{\left({ }_{\mathrm{e}} \phi_{\mathrm{u}}-{ }_{\mathrm{e}} \phi_{\mathrm{y}}\right)}{\left({ }_{\mathrm{e}} \mathrm{M}_{\mathrm{u}}-{ }_{\mathrm{e}} \mathrm{M}_{\mathrm{y}}\right)} \quad \cdots \cdots \quad$ (23) 
ここで

$\Delta_{\mathrm{c}} \mathrm{M}, \Delta_{\mathrm{e}} \mathrm{M}$ : 端部降状以後のスパン中央部, 端部の増加 モーメント

${ }_{\mathrm{c}} \mathrm{B}, \mathrm{e} \mathrm{B}$ ：それぞれスパン中央部，端部において，端 部降伏後に曲率が増大寸るものと仮定した 部分の長さ（本論では, $\mathrm{cB}=93.3 \mathrm{~cm}, \mathrm{e} \mathrm{B}=$ $10 \mathrm{~cm}$ に設定)

$\Delta_{\mathrm{c}} \phi, \Delta_{\mathrm{e}} \phi:{ }_{\mathrm{c}} \mathrm{B}, \mathrm{e}_{\mathrm{e}} \mathrm{B}$ 区間における平均増加曲率 $\mathrm{c} \phi_{\mathrm{y}}, \mathrm{c} \phi_{\mathrm{c}}$ : 中央断面の降伏時曲率, ひびわれ時曲率

$\mathrm{e} \phi_{\mathrm{u}}, \mathrm{e} \phi_{1}$ : 端部断面の圧縮ひずみ $\varepsilon_{\mathrm{c}}=2500 \mu$ 時曲率, 降伏時曲率

${ }_{c} \mathrm{M}_{\mathrm{y}}, \mathrm{c} \mathrm{M}_{\mathrm{c}}$ ：中央断面の降伏モーメント，ひびわれ時モ一 メント

$\mathrm{e} \mathrm{M}_{\mathrm{u}, \mathrm{e}} \mathrm{M}_{\mathrm{y}}{ }^{\prime}$ ：端部断面の圧縮ひずみ $\varepsilon_{\mathrm{c}}=2500 \mu$ 時モーメ ント，降伏時モーメント

ここで；増加荷重を $\Delta \mathrm{P}_{\mathrm{L}}$ とすると， 3 等分点 2 点集中 載荷による場合の全仕事量は $\Delta \mathrm{P}_{\mathrm{L}} \cdot \mathrm{L} / 6$ であり,この值が 中央部と端部の増加モーメントの合計と等しくなるので

$\Delta_{\mathrm{c}} \mathrm{M}+\Delta_{\mathrm{e}} \mathrm{M}=\Delta \mathrm{P}_{\mathrm{L}} \cdot \mathrm{L} / 6$ (24)

となる。 $\alpha_{2}$ は, 完全固定梁の 3 等分点 2 点集中載荷時の 端部増加曲げモーメント $\Delta_{\mathrm{e}} \mathrm{M}_{\mathrm{com}}=\Delta \mathrm{P}_{\mathrm{L}} \cdot \mathrm{L} / 9$ に対する比で あるので，下式で与えられる。

$$
\alpha_{2}=\frac{\Delta_{\mathrm{e}} \mathrm{M}}{\Delta_{\mathrm{e}} \mathrm{M}_{\mathrm{com}}}=\frac{1.5 \cdot \beta_{\mathrm{c}}}{\left(\beta_{\mathrm{e}} \cdot \mathrm{c} \mathrm{B} / \mathrm{e} \mathrm{B}+\beta_{\mathrm{c}}\right)}
$$

4) 端部ひびわれによる曲げモーメントの再配分

図ー8に示すように，端部のひびわれ発生モーメント e $\mathrm{M}_{\mathrm{c}}$ ，コンクリートの引張を無視した場合の同曲率でのモ一 メントを $\mathrm{eM}_{\mathrm{c}}$ とすると，瞬時にひびわれが中立軸位置ま で達した場合 $\mathrm{M}^{\prime}\left(={ }_{\mathrm{e}} \mathrm{M}_{\mathrm{c}}-{ }_{\mathrm{e}} \mathrm{M}_{\mathrm{c}}{ }^{\prime}\right)$ のモーメントが不足する ことになる。次にその不足分が分布係数 $\alpha_{1}$ にしたがって 端部，中央部に配分されるとすれば，端部の曲げモーメ ント $\mathrm{e} \mathrm{M}$ は,

$$
{ }_{\mathrm{e}} \mathrm{M}={ }_{\mathrm{e}} \mathrm{M}_{\mathrm{c}}{ }^{\prime}+\mathrm{M}^{\prime} \cdot 2 / 3 \cdot \boldsymbol{\alpha}_{1}
$$

となり, 結果的には，下式の正曲げモーメントが作用し たものと同値となる。

$$
\begin{aligned}
\mathbf{M}^{\prime \prime} & ={ }_{\mathrm{e}} \mathrm{M}_{\mathrm{c}}-{ }_{\mathrm{e}} \mathrm{M} \\
& =\left(1-2 / 3 \cdot \alpha_{1}\right) \cdot\left({ }_{\mathrm{e}} \mathrm{M}_{\mathrm{c}}-{ }_{\mathrm{e}} \mathrm{M}_{\mathrm{c}}{ }^{\prime}\right)
\end{aligned}
$$

ここでは，この値を付加モーメントとして，ひびわれ発 生から端部降伏までの荷重に比例させて加算する。

5) たわみの計算

スパン中央部のたわみ $\delta_{\mathrm{p}}$ は, 部材をスパン方向 $\mathrm{n}$ 節点 （n=26）に分割し各点での曲率を求め下式を用いて計算 する。

$$
\begin{aligned}
\delta_{\mathrm{p}} & =(\mathrm{L} / 2) \cdot \int_{0}^{\mathrm{L} / 2} \phi(\mathrm{X}) \mathrm{dx}-\int_{0}^{\mathrm{L} / 2} \phi(\mathrm{X}) \cdot(\mathrm{L} / 2-\mathrm{X}) \mathrm{dx} \\
& =(\mathrm{L} / 2) \cdot \sum_{\mathrm{i}=1}^{\mathrm{n} / 2} \phi\left(\mathrm{X}_{\mathrm{i}}\right)-\sum_{\mathrm{i}=1}^{\mathrm{n} / 2} \phi\left(\mathrm{X}_{\mathrm{i}}\right) \cdot\left(\mathrm{L} / 2-\mathrm{X}_{\mathrm{i}}\right) \quad \cdots \quad(28)
\end{aligned}
$$

\section{3. 実験結果と解析結果の比較}

\begin{tabular}{|c|c|c|c|c|c|c|}
\hline & \multicolumn{2}{|c|}{ Ooth九荷重 (t $f$ ) } & \multicolumn{2}{|c|}{ 降代荷重 $(t f)$} & \multirow{2}{*}{ 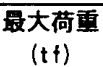 } \\
\hline & & 部 & 中央部 & 端 部 & 中央部 & \\
\hline \multirow{3}{*}{ R18S } & 実㥂傎 & & 3.8 & $=$ & 7.5 & 7.8 \\
\hline & 部算值 & 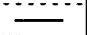 & 3.8 & - & 7.4 & 8.1 \\
\hline & 計 /実 & $=$ & 1.00 & - & 0.99 & 1.04 \\
\hline \multirow{3}{*}{ R2OS } & 実駼值 & 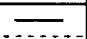 & 4.6 & & 9.9 & 10.1 \\
\hline & 訐算值 & $-\cdots$ & 3.8 & 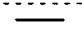 & 9.1 & 9.9 \\
\hline & 計 $/$ 実 & 工 & 0.83 & - & 0.92 & 0.98 \\
\hline \multirow{3}{*}{ C25S } & 実駼值 & - & 3.6 & 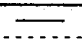 & 10.7 & 11.0 \\
\hline & 計算直 & $\cdots$ & 4.4 & & 10.2 & 11.5 \\
\hline & 計/実 & $\bar{Z}$ & 1.22 & $\longrightarrow$ & 0.95 & 1.05 \\
\hline \multirow{3}{*}{ R18F } & 実畭值 & 3.6 & 8.0 & 10.4 & 13.2 & 13.9 \\
\hline & 計算值 & 2.7 & 7.6 & 8. 4 & $12: 8$ & 13.6 \\
\hline & 計/実 & 0.75 & 0.95 & 0.81 & 0.97 & $0 . \overline{98}$ \\
\hline \multirow{3}{*}{$\mathrm{R} 2 \mathrm{OF}$} & 実硷㨁 & 3.2 & 6.0 & 10.8 & 15.8 & 16.1 \\
\hline & 計算镇 & 3.0 & 7.8 & 9.2 & 15.5 & 16.4 \\
\hline & 計/実 & 0.94 & 1. 30 & 0.85 & 0.98 & 1.02 \\
\hline \multirow{3}{*}{$\mathrm{C} 25 \mathrm{~F}$} & 実捨值 & 3.0 & 6.8 & 9.8 & 14.8 & 16.6 \\
\hline & 許賈值 & 4.0 & 6.5 & 7.4 & 14.5 & 15.7 \\
\hline & 計/实 & 1.33 & 0.96 & 0.76 & 0.97 & 0.95 \\
\hline
\end{tabular}

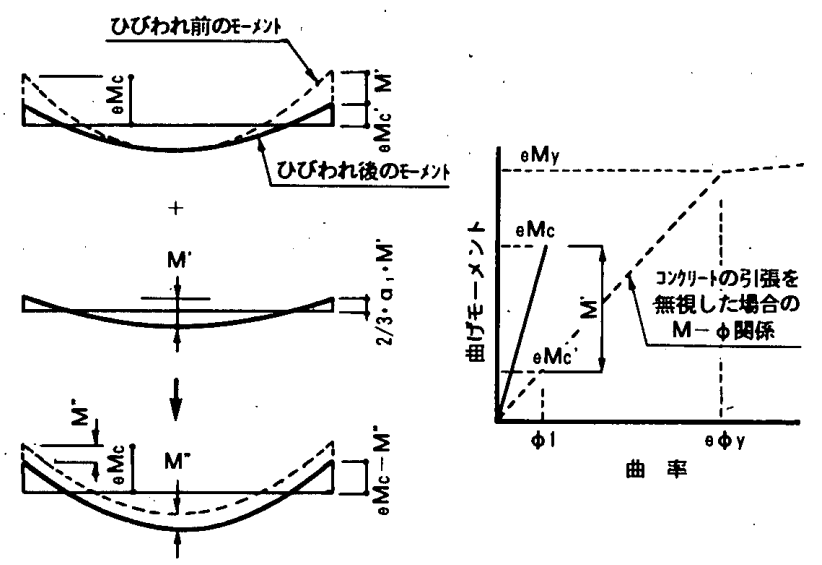

图－8 端部ひびわれによる応力再配分の概念

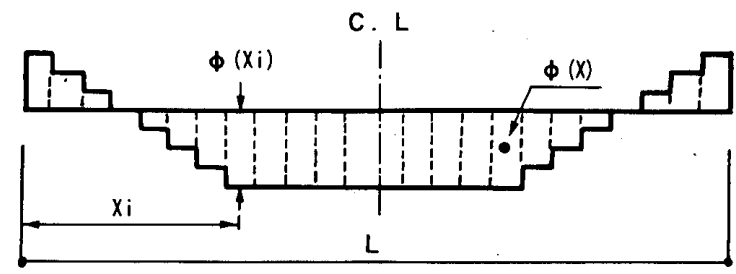

図ー9たわみの算定方法

表-4 実験結果と解析結果の比較

表 -4 , 図-10，11に実験結果と解析結果を示す。表一 4 はひびわれ，降伏および最大荷重を，図一10は曲率に ついて, 図一11は，荷重一たわみ関係について比較した ものである。表ー4よりわかるように, 端部の降伏荷重 計算值が実験值に比べやや低くなっているものの，中央 部のひびわれ，降伏，最大荷重は実験值とよく合致して おり，耐力的にはほぼよい対応をしているものと考えら れる。また，図一10，11においては，固定支持試験体の 端部曲率計算値が端部降伏荷重計算値以後は実験値に比 べ相当大きな值を示し，たわみ計算值も実験值に対しや 

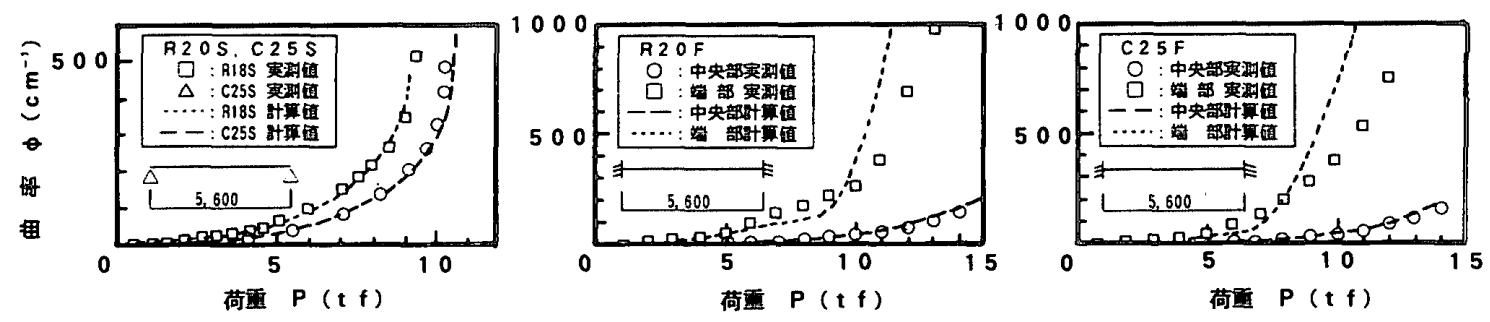

図-10 曲率一荷重関係
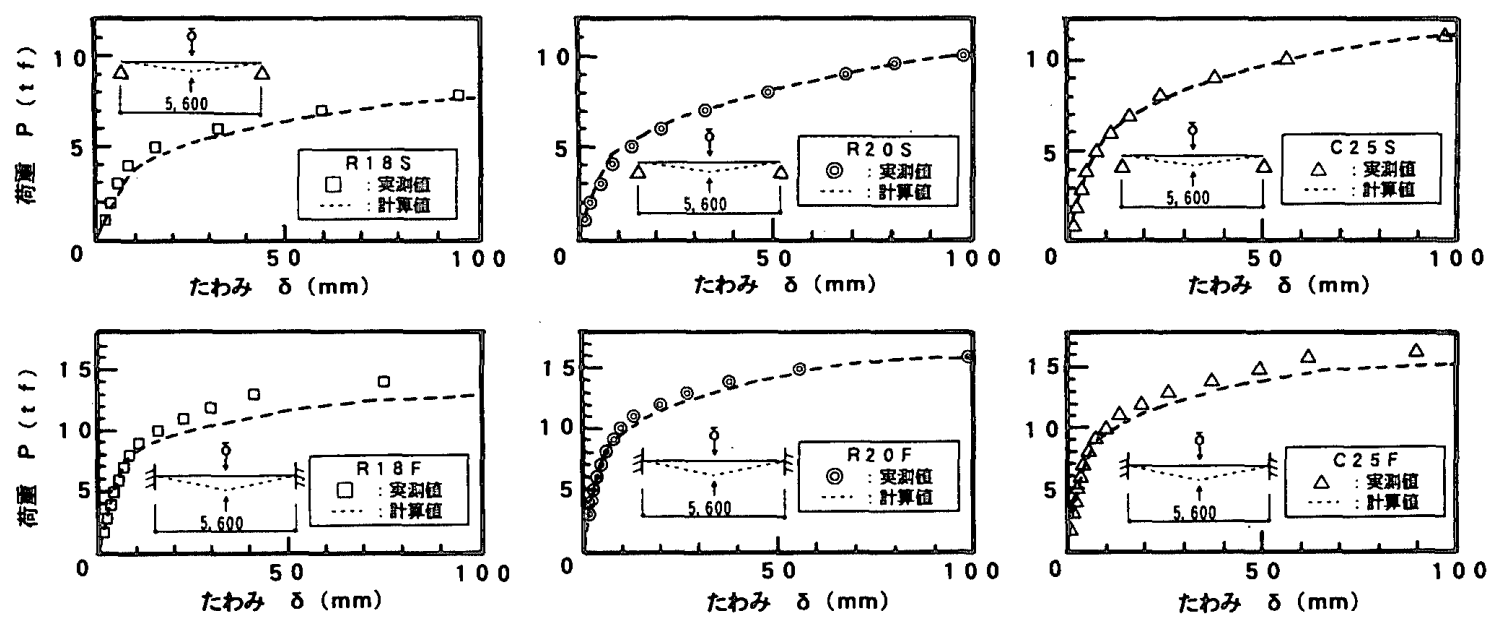

图-11 荷重一たわみ関係

や大きめな值を示しているが，それ以外の範囲や単純支 持試験体については曲率，たわみ共によく合致している。 この傾向は，50cm幅の試験体である R18F に比較的よく現 れているところから，小森 ${ }^{15)}$ が指摘している面内圧縮力 などの影響が考えられる。しかし，耐力を含め全般的に はおおよそよい対応を示しており，さらに通常の使用状 態では端部上ば筋が降伏以前であることを勘案すると, 精度上は支障ないものと考られる。

\section{3．長期載荷によるたわみ性状}

\section{1 実験概要}

\section{1) 試験体}

試験体は，チャンネル型断面を有する PC 板と場所打ち コンクリートからなる実物大の合成床スラブ 4 体である。

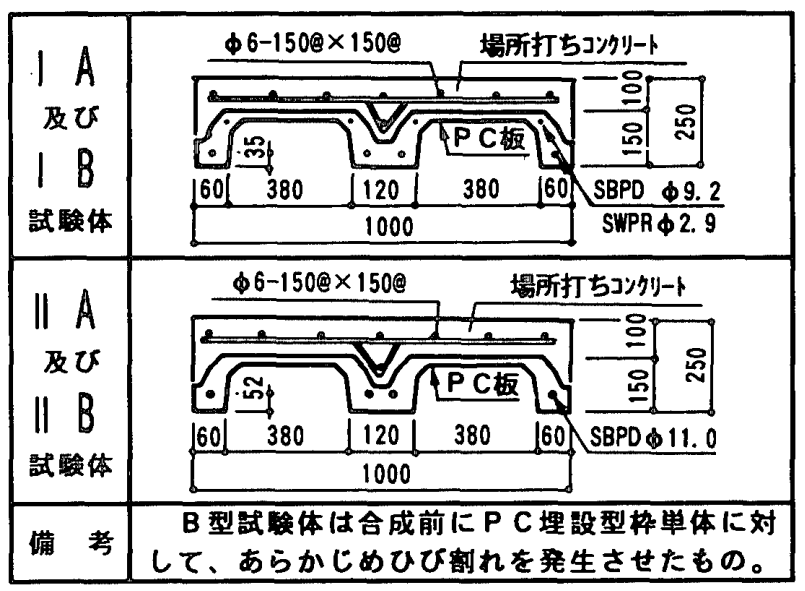

图-12 試験体面詳細 断面詳細を図一12に，形状および寸法を図一13に，使用 材料の性質および規格などを表一 $5 ， 6$ に示す。試験体は， I， II 型とも PC 板形状はほとんど同じで あるが，表一6に示すように I 型 では異形 $\mathrm{PC}$ 鋼棒 $\phi 9.2 \mathrm{~mm}$ と $\mathrm{PC}$ 鋼 より線 $\phi 2.9 \mathrm{~mm}$ ，II型では翼形 $\mathrm{PC}$ 鋼棒 $\phi 11 \mathrm{~mm}$ を使用しており，導入 プレストレス量を変えている。ま た，A 型試験体の PC 板は健全で

\begin{tabular}{|c|c|c|c|c|c|c|c|c|}
\hline & \multicolumn{4}{|c|}{ プレキャスト部分 } & \multicolumn{4}{|c|}{ 㙕所打与部分 } \\
\hline & $\begin{array}{l}\text { 材令 } \\
\text { (日) }\end{array}$ & 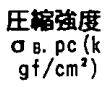 & $\begin{array}{c}\text { 引張強度 } \\
\sigma \quad . \quad p c(k \\
\left.\mathrm{g} t / \mathrm{cm}^{2}\right)\end{array}$ & $\begin{array}{c}\text { 燀性保数 } \\
\text { E. } \mathrm{pc}(\mathrm{kg} \\
\left.\mathrm{f} / \mathrm{cm}^{2}\right)\end{array}$ & $\begin{array}{l}\text { 材令 } \\
\text { (日) }\end{array}$ & $\begin{array}{c}\text { 压埦強度 } \\
\text { O B. ca(k } \\
\left.\mathrm{g}^{\prime} / \mathrm{cm}^{2}\right)\end{array}$ & $\begin{array}{c}\text { 引張強度 } \\
\sigma_{t} \cdot \mathrm{ca}^{(\mathrm{k}} \\
\left.\mathrm{g}^{\dagger} / \mathrm{cm}^{2}\right)\end{array}$ & 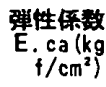 \\
\hline 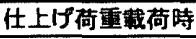 & 35 & 580.9 & 38.7 & 2. $6 \times 10^{5}$ & 7 & 131.5 & 12.7 & $1.8 \times 10^{5}$ \\
\hline 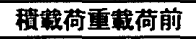 & 42 & 626.3 & 40.5 & $2.6 \times 10^{5}$ & 14 & 158.7 & 15.9 & $1.9 \times 10^{5}$ \\
\hline 各 4 摁強度 & 28 & 554.5 & 33.2 & $2.5 \times 10^{5}$ & 28 & 178.1 & 15.9 & $1.9 \times 10^{5}$ \\
\hline 各材命 30 週 & 210 & 676.9 & 43.4 & $2.8 \times 10^{5}$ & 210 & 206.8 & 12.9 & $2.0 \times 10^{5}$ \\
\hline 各材令 1 年 & 365 & 641.0 & 39.0 & $2.8 \times 10^{5}$ & 365 & 212.6 & 16.1 & $2.1 \times 10^{5}$ \\
\hline 各材令 1 年半 & 550 & 708.3 & 43.8 & $2.8 \times 10^{5}$ & 545 & 206.3 & 17.8 & $2.1 \times 10^{5}$ \\
\hline 各材令 3年 1 力月 & 1124 & 652.7 & -- & $2.6 \times 10^{5}$ & 1097 & 199.0 & $-\cdots$ & $2.0 \times 10^{5}$ \\
\hline
\end{tabular}


表－6 使用鋼材およびプレストレス

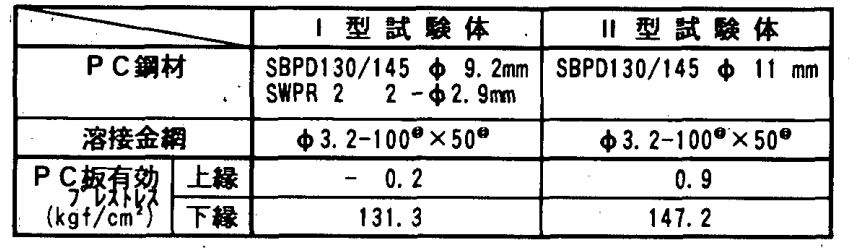

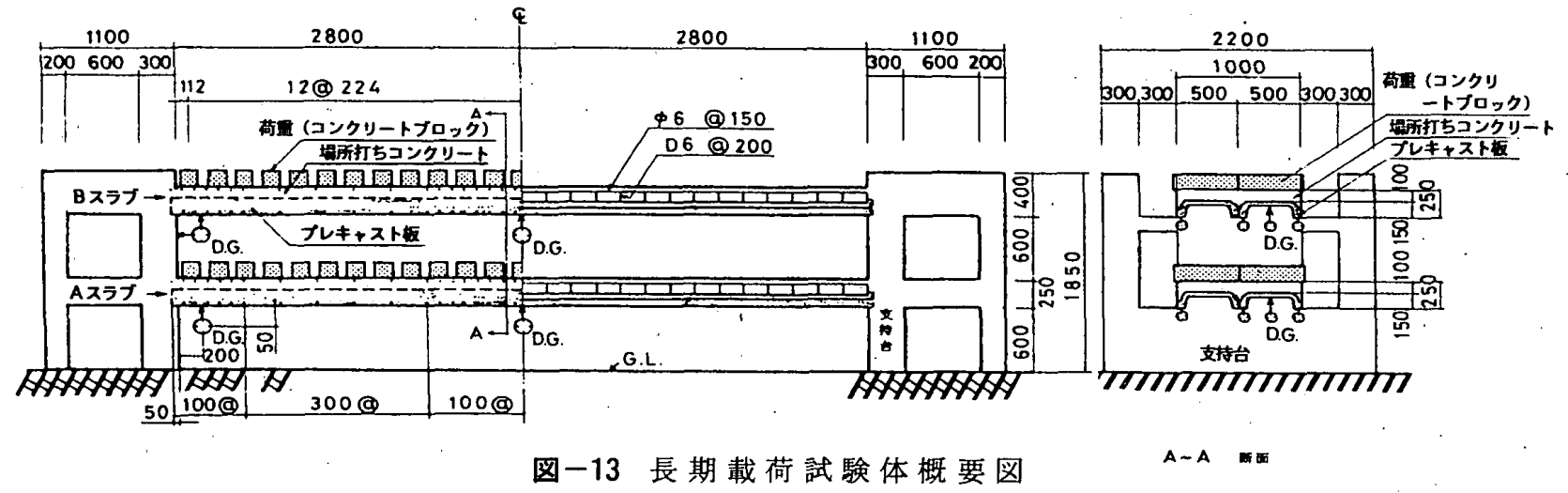

あるが，B 型試験体は場所打ちコンクリート打設時（施工 時）におけるオーバーロードを想定し，合成する前に PC 板中央部下縁にあらかじめひびわれを発生させた。試験 体は，これら PC 板に $10 \mathrm{~cm}$ 打ち増して，リブ高を $25 \mathrm{~cm}$ とし た合成床スラブであり；全試験体ともスパン $5.6 \mathrm{~m}$ の両端 固定スラブとなっている。

\section{2 ) 実験方法}

長期設計荷重としては, 仕上げ荷重 $60 \mathrm{kgf} / \mathrm{m}^{2}$, 積載荷重 $180 \mathrm{kgf} / \mathrm{m}^{2}$ ，の合計 $240 \mathrm{kgf} / \mathrm{m}^{2}$ を設定し，ゴム性樹脂コー ティング加エしたコンクリートブロック $(\mathrm{B} \times \mathrm{H} \times \mathrm{L}=15 \times$ $15 \times 52 \mathrm{~cm}$, 平均重量 $27 \mathrm{~kg} /$ 個) を, 全長にわたって均等に 載荷した。実験日程は実際の施工工程を模擬し，PC 板製 作後28日目に場所打ちコンクリートを打設し，36日目（場 所打ちコンクリートの材令で 8日）に仕上げ荷重を載荷, 43日目（場所打ちコンクリートの材令で15日）に積載荷 重を載荷した。また測定は，合成床スラブのスパン中央 部执よび両端部のたわみを $1 / 100 \mathrm{~mm}$ 精度のダイヤルゲー ジで，また床スラブ上下縁から $2.5 \mathrm{~cm}$ 内側線上の検長間 隔 $10 \mathrm{~cm}, 30 \mathrm{~cm}$ の伸縮をベリー式ストレインゲージとノギ スで測定した。そのほか, 湿度を乾湿度計で測定した。

\section{2 長期たわみの算定法}

長期たわみの計算フローを図ー14に示す。長期たわみ は2.2と同様に，部材をスパン方向37節点に分割し，それ ぞれの点での増加曲率を計算しモールの定理により計算 する。長期たわみの算定上考慮する項目は，(1)リープ, (2)乾燥収縮，(3)端部上ば筋の抜出しの3 項目とした。解 析上の仮定を以下に示す。

1) クリープ俰数および乾燥収縮度

クリープ係数および乾燥収縮度は, コンクリートの材
表ー7クリープ係数执よび乾燥収縮度

\begin{tabular}{|c|c|c|c|}
\hline & IA. II A & I B. II B \\
\hline クリープ & $P$ C板部 & 2.00 & 1.50 \\
\hline 係 数 & 場所打部 & 4.00 & 3.00 \\
\hline \multirow{2}{*}{$\begin{array}{l}\text { 乾 煌 } \\
\text { 叹㜚度 }\end{array}$} & $P$ C 板部 & $250 \times 10^{-6}$ & $200 \times 10^{-6}$ \\
\hline & 坥所打部 & $400 \times 10^{-6}$ & $300 \times 10^{-8}$ \\
\hline
\end{tabular}


4) スラブ上ば筋の抜出し

鉄筋の抜出しは，小柳 ${ }^{22}$ による提案式に従うものとし た。瞬時の抜出し量および付着クリープ係数は，下記の とおりである。

$$
\begin{aligned}
& \Delta \mathrm{S}=5 \cdot \sigma_{\mathrm{s}} \times 10^{-6} \\
& \mathrm{~K}_{\mathrm{t}}=\frac{\mathrm{t}}{1.28 \cdot \mathrm{t}+17.5} \\
& \sigma_{\mathrm{s}} \text { : 鉄筋の引張応力度 }\left(\mathrm{kgf} / \mathrm{cm}^{2}\right) \\
& \mathrm{t} \text { : 経過日数（日） }
\end{aligned}
$$

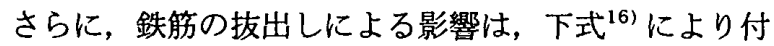
加モーメント ${ }_{\mathrm{L}} \mathrm{M}_{\mathrm{s}}$ として考虑した。

$$
\begin{aligned}
\theta_{\mathrm{s}} & ={ }_{\mathrm{s}} \theta+{ }_{\mathrm{cr}} \theta \\
& =\frac{\Delta \mathrm{S} \cdot\left(1+\mathrm{K}_{\mathrm{t}}\right)}{\mathrm{d}_{\mathrm{s}}-\mathrm{x}}
\end{aligned}
$$$$
{ }_{\mathrm{L}} \mathrm{M}_{\mathrm{s}}=2 \cdot \theta_{\mathrm{s}} \cdot \mathrm{E}_{\mathrm{c}} \cdot \mathrm{I}_{\mathrm{c}} / \mathrm{L}
$$

$$
\text { ここに, }
$$

$\theta_{\mathrm{s}}:$ 鉄筋の拔出しによる端部の回転角

${ }_{\mathrm{s}} \theta:$ 鉄筋の瞬時抜出しによる回転角

$\operatorname{cr} \theta ：$ 鉄筋の経時的拔出しによる回転角

$\mathrm{E}_{\mathrm{c}}:$ 弹性係数

$I_{c}$ : 断面二次モーメント

$\mathrm{x}$ : 圧縮縁から中立軸までの距離

\section{3 実験結果と解析結果の比較}

まず，実験結果について述べる。試験体 I A, II Aは,

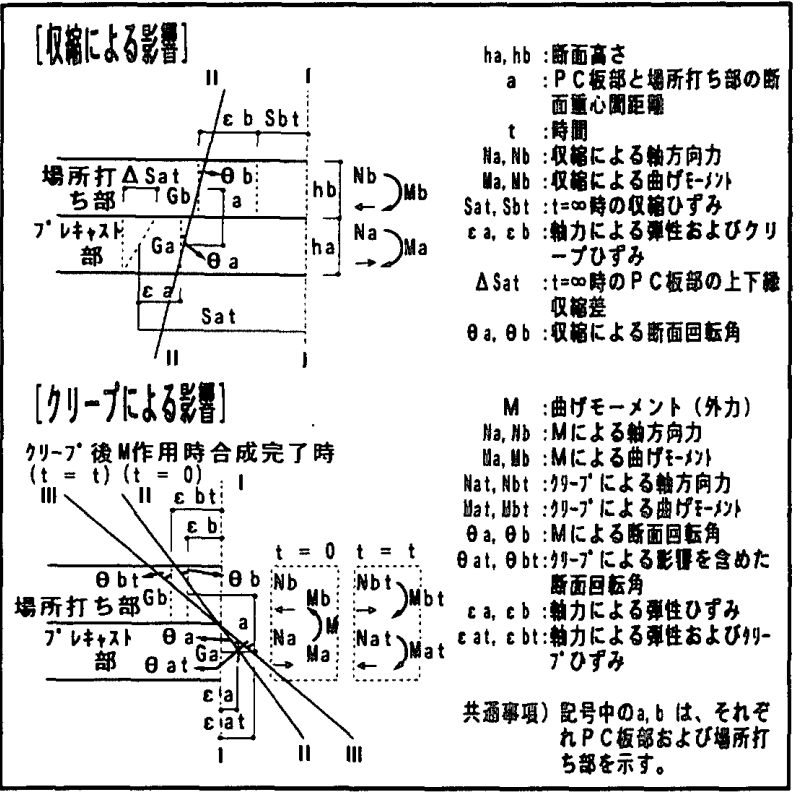

图-15 収縮およびクリーブによる影響

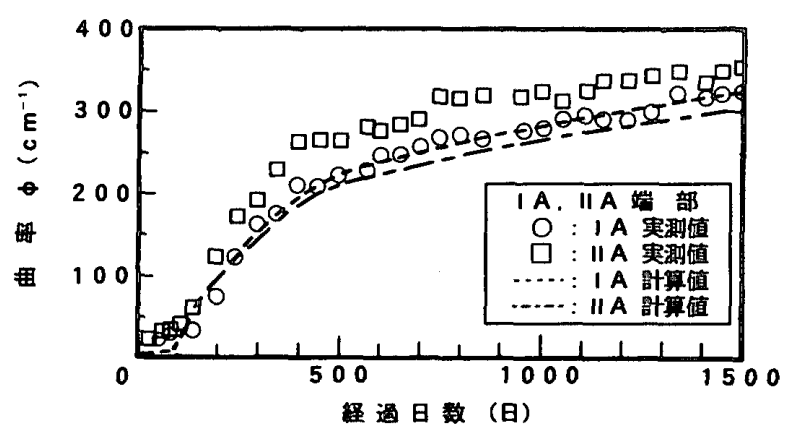

a. I A. II A 端部碎面

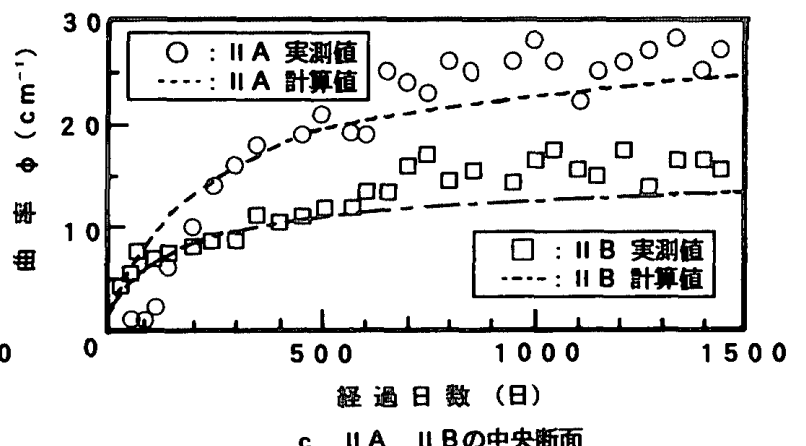

c. II A 、 ॥Bの中央断面

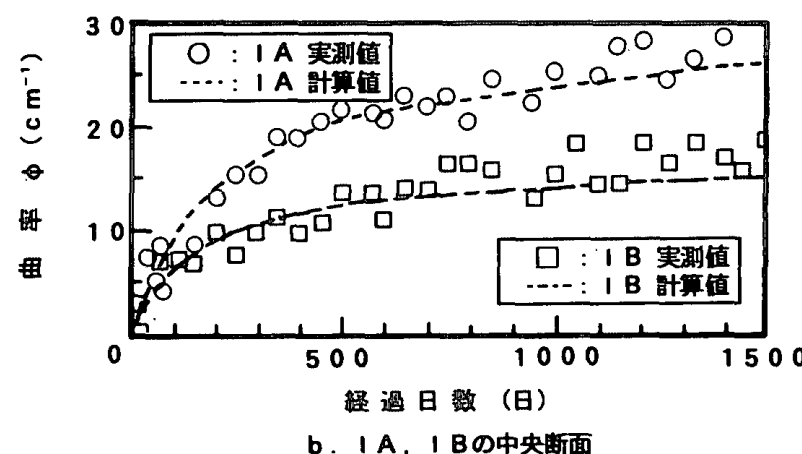

図-16 曲率一経過日数関倸
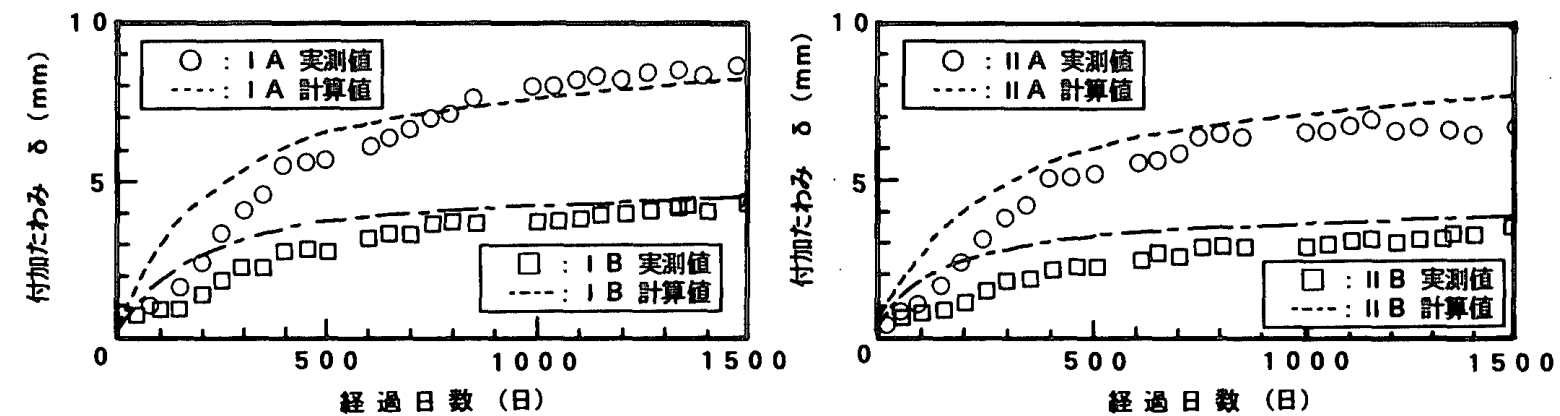

図-17付加たわみ一経過日数関係 

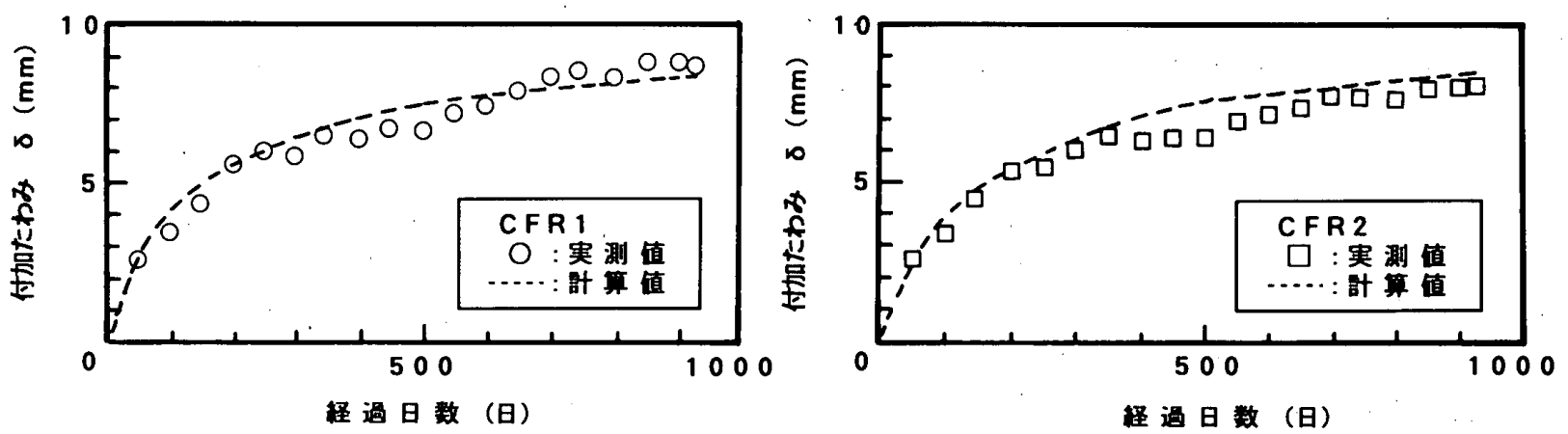

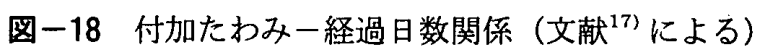

載荷後約100日で端部にひびわれが発生し，端部 $10 \mathrm{~cm}$ 区間 の平均曲率が経過日数 1500 日で約 $300 〜 350 \times 10^{-6}$ まで達 した。上ば能量は， $\mathrm{A}_{\mathrm{s}} / \mathrm{b} \cdot \mathrm{d}_{\mathrm{s}}=0.09 \%$ と非常に小さく, 曲率の増加量から判断し, 上ば筋による補強効果はほと んどなかった。また I B，II Bは，A型とは対照的に載 荷後約1500日まで端部にひびわれは発生しなかった。こ れらの相違の原因としては, 端部の固定度の違いが考え られる。解析上は, 以上の結果に基づき I A， II A では材 令 100 日以後を単純支持として，I B， II Bではひびわれ による応力分配や鉄筋の抜出しは無視することとした。 図－16，17に実験結果と解析結果を示す。図－16は，ス パン中央部および端部の曲率変化について, 図一17は付 加たわみについて比較したものである。同図からわかる ように曲率の増加および付加たわみともに計算值はおお よそ実験値をとらえているようである。また図ー18は,

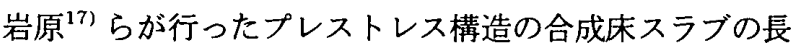
期たわみ実験結果と本解析法による計算結果を比較した ものである。試験体の断面は，2.1の R18F と同じでスパ ン $\mathrm{L}=5.60 \mathrm{~m}$ であり, CFR1 では $\mathrm{w} \ell=240 \mathrm{kgf} / \mathrm{m}^{2}, \mathrm{CFR} 2$ では $430 \mathrm{kgf} / \mathrm{m}^{2}$ の積載荷重を載荷している。両試験体とも 経過日数が小さいうちから計算值と実験值がよく合致し ており，解析的には十分な精度であると判断される。

\section{4. 合成床スラブの長期たわみについて}

図ー19は, 本解析法を用いた長期たわみ量の試算結果 である。試算条件としては, R18F， C25F の断面を対象 とし, 支持条件は両端固定, 積載荷重 $\mathrm{w} l=240 \mathrm{kgf} / \mathrm{m}^{2}$, スパン $5.0 \sim 7.5 \mathrm{~m}$ とた。また端部のひびわれは，載荷 直後に発生するものと仮定した。スラブ施工時の支持条 件は実情に合わせ， R18F では場所打ちコンクリートを打 設する際中央 1 点サポート, C $25 \mathrm{~F}$ では中間サポートなし とした。なお，図中の弾性たわみは，全荷重が両端固定 の合成断面に作用したとして求めた值である。図による と, $\mathrm{C} 25 \mathrm{~F}$ は D/L (スラブ全せい/スパン) $=1 / 20 \sim 1 / 30$ であり，上ば筋の影響はあまりなくたわみも学会 RC 規 淮 ${ }^{18)}$ の推奖值 $\mathrm{L} / 400$ の約半分程度であることがわかる。
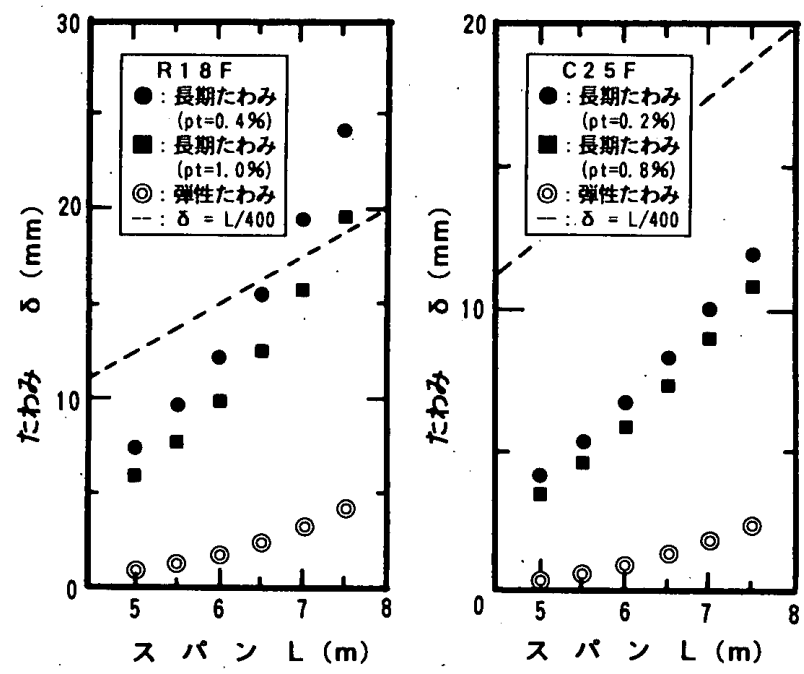

图ー19 長期たわみの試算結果

一方 $\mathrm{R} 18 \mathrm{~F}$ は，同じく $\mathrm{D} / \mathrm{L}=1 / 28 \sim 1 / 42$ となり， $7 \mathrm{~m}$ 近 辺では $\mathrm{L} / 400$ を越え，このあたりでは鉄筋量により $4 \sim 5 \mathrm{~mm}$ のたわみ制御が可能であることがわかる。両断面とも設 定したスパン内であればIII種 PRC 造の床スラブ ${ }^{10)}$ として の設計が可能であるが，D/L が1/35程度からは応力によ る配筋量算定の他にたわみ制御の観点からも検討を加え る必要があるものと判断される。また，弾性たわみに対 する長期たわみの比は, おおよそ 5〜8倍となり, 鉄筋コ ンクリート床スラブの場合 ${ }^{18)}$ に比べ $1 / 3 \sim 1 / 2$ となること がわかった。

\section{5. 結 論}

プレストレスを導入した PC 板を用いた合成床スラブの たわみ算定法を提案し検討を行った結果, 以下の結論が 得られた。

（1）合成床スラブの荷重一たわみ関係は，偏心軸圧縮力 を受ける合成断面として算定した $\mathrm{M}$ - 関係を用いるこ とにより，実験結果とよく対応した合理的な解析結果 が得られた。

(2) 合成床スラブの材令一曲率関係は，坂らによる増加 曲率算定の提案式で推定可能であり，これにより長期 
たわみを解析的に追跡できる。

（3）試算によると，合成床スラブの場合 $\mathrm{D} / \mathrm{L}=1 / 35$ 以下 で長期たわみが学会 RC 規準の推奨值を越えることが 予想されるので，端部上ば㳙の算定においてはたわみ 制御の観点から配筋を増すことが望ましいと考えられ る。

（4）合成床スラブの長期たわみ倍率は，5～8 倍と推定さ れ，鉄䇨コンクリート造床スラブに比べ, $1 / 3 \sim 1 / 2$ と 小さいことがわかった。

\section{[謝辞〕}

実験にあたり本学技官永藤政敏氏および学生諸氏に多 大なるご協力をいただいた。また，熊本工業大学岩原助 教授より貴重な資料を提供していただいた。ここに檿く 御礼申し上げます。

\section{參考文献}

1）小森清司ほか 3 名：PC 板埋設型枠を用いた合成休スラブの長 期载荷実験, 第 3 回コンクリート工学年次講演会講演論文集, pp. 349 352, 1981

2）小森清司ほか 2 名: PC 板埋設型枠を用いた鉄筋コンクリート 林スラブの載荷実験（その 2 , 長期截荷実験の中間報告)，日 本建築学会大会学術講演講概集, pp. 1393 1394, 昭和56年9 月

3）小森清司ほか 2 名：PC 板埋設型枠を用いた鉄筋コンクリート 床スラブの載荷実験（その3，長期载荷実験の中間報告)，白 本建築学会九州支部研究報告, pp. 161 164, 昭和57年3月

4）小森清司ほか 2 名：PC 板埋設型枠を用いた鉄筋コンクリート 林スラプ载荷実験（その 4 ，長期载荷実験の中間報告），日 本建築学会大会学術講演請概集, pp. 1397 1398, 昭和57年10 月

5）小森清司ほか 2 名：逆 T 形の PC 板埋設型枠を用いた合成床 スラブの载荷実験, 日本建築学会九州支部研究報告, pp. 257 $260,1991.3$

6）田中恭哉ほか 1 名：空胴部を設けた合成床スラブに関する実 験的研究, 日本建築学会大会学術講演講概集, pp. 1081 1082, 1993.9
7) 松崎育弘ほか 1 名: 空胴プレストレストコンクリートパネル 合成床スラブに関する実験研究, 日本建筑学会大会学術講演 講概集, pp. 2027 2028, 昭和59年10月

8）五味久忠ほか 7 名：高強度鉄筋にてプレストレスを導入した プレキャスト板を用いた中空合成床板の持続載荷実験（その 1 , 持続載荷実験 5 々月間の举動) 日本建策学会大会学術講 演講概集，pp. 1073 1074，1992.10

9 ）日本建筮学会：プレストレストコンクリート設計施工規淮・ 同解説（1987年版）

10）日本建築学会：プレストレスト鉄筋コンクリート（III種 PC) 構造設計・施工指針・同解説（1986年制定）

11）東洋一, 小森清司：铁筇コンクリート帯スラブの長期たわみ に関する実験的研究(2), 日本建築学会大会講演講概集, pp. $1837 \sim 1838$, 昭和 52 年 10 月

12）小柳光生：鉄筋コンクリート床スラブの長期たわみに関する 研究, 学位論文, pp. 87, 昭和60年11月

13）坂, 岡田, 六車: プレストレストコンクリート, pp. 403 416, 朝倉書店

14）猪股俊司：構造コンクリート曲げ部材使用限界状態の統一設 計計算法，コンクリート工学論文，Vol.26，N0.12，Dec. 1988

15）小森清司：鉄筋コンクリートスラブの耐力とたわみ性状に関 する研究(1) (変動面内力を考虑した RC一方向スラブの耐力 とたわみの算定法), 日本建築学会論文報告集, 第269号, 昭 和53年7月

16）井野智ほか3名：鉄筋コンクリート床スラブの端部上ば铁肪 定着部の伸びによる付加たわみの概算法, コンクリート工学 年次論文報告集, pp. 149 154, Vol. 14，No. 2， 1992

17）岩原昭次ほか 2 名：逆 $\mathrm{T}$ 型 $\mathrm{PC}$ 埋設型枠を用いた合成床スラ ブの持続荷重下における力学的研究（その3，経過日数約 900 日までの長期変形実験結果), 日本建築学会九州支部研究報告, pp. 241 244, 1994.3

18）日本建築学会：鉄筋コンクリート構造計算規準・同解説（1991 年版)，付録 13

19）小森清司ほか 2 名：ひし形網目状の粗面を打継ぎ面に有する 合成床スラブの打継ぎ部せん断耐力に関する研究, 日本建策 学会構造系論文集, 第458号, pp. 89 98, 1994.4

(1994 年 1 月 7 日原稿受理, 1994 年 10 月 4 日採用决定) 